\title{
'Now that you mention it, museums probably are a target': museums, terrorism and security in the United Kingdom
}

\author{
Colin Atkinson, Donna Yates, Nick Brooke
}

\begin{tabular}{|l|l|}
\hline Date of deposit & 06112019 \\
\hline Document version & Author's accepted manuscript \\
\hline Access rights & $\begin{array}{l}\text { Copyright @ 2019 Informa UK Limited, trading as Taylor \& } \\
\text { Francis Group. This work has been made available online in } \\
\text { accordance with publisher policies or with permission. Permission } \\
\text { for further reuse of this content should be sought from the } \\
\text { publisher or the rights holder. This is the author created accepted } \\
\text { manuscript following peer review and may differ slightly from the } \\
\text { final published version. }\end{array}$ \\
\hline $\begin{array}{l}\text { Citation for } \\
\text { published version }\end{array}$ & $\begin{array}{l}\text { Atkinson, C, Yates, D \& Brooke, N (2019), "Now that you mention } \\
\text { it, museums probably are a target': museums, terrorism and } \\
\text { security in the United Kingdom', Museum Management and } \\
\text { Curatorship, vol. Latest Articles }\end{array}$ \\
\hline $\begin{array}{l}\text { Link to published } \\
\text { version }\end{array}$ & \begin{tabular}{l} 
https://doi.org/10.1080/09647775.2019.1683881 \\
\hline
\end{tabular}
\end{tabular}

Full metadata for this item is available in St Andrews Research

Repository at: https://research-repository.st-andrews.ac.uk/ 


\title{
'Now that you mention it, museums probably are a target': museums, terrorism and security in the United Kingdom
}

\begin{abstract}
This article explores counter-terrorism security practices at museums in the United Kingdom (UK), locations that terrorists have targeted through both propaganda and operational activity. Drawing upon research that re-interprets the museum within the 'single narrative' of global jihadist terrorism, an outlook that justifies and legitimises the targeting of socio-cultural sites from instrumental and symbolic perspectives, this article highlights the important roles of the police Counter Terrorism Security Adviser (CTSA) and the museum security manager in counter-terrorism practice at museums in the UK. The practices of highlighting risk to the museum and managing risk in the museum environment are subsequently outlined. In doing so two key challenges facing counter-terrorism security practice in the museum are noted: the cost of implementing counter-terrorism measures and the cultural challenge of communicating and responsibly embedding such security thinking in everyday practice. The researchers also reflect upon the potential consequences of the implementation of counter-terrorism security measures at museums as a form of securitisation.
\end{abstract}

\section{Keywords}

Museum security, counter-terrorism, policing, securitisation, communities

\section{Introduction}

Terrorist attacks in recent years have demonstrated a diversity of targets in Western Europe and beyond: from concert venues, nightclubs, football stadia, Christmas markets, and pedestrian malls to airports, metro stations, bridges and parliaments. Within this litany of locations, museums have also featured as a site of terrorist violence on multiple occasions and in a variety of jurisdictions in the past decade. For example, in 2009 James Wenneker von Brunn, an anti-Semitic white supremacist, conducted a firearms attack at the United States Holocaust Memorial Museum in Washington, DC, killing a security guard (White 2017, 35). In 2014, Mehdi Nemmouche, a French national of Algerian origin who had returned to Europe having spent time with Islamic State in Syria, conducted an attack at the Jewish Museum in Brussels, killing four people (Vidino 2014, 219).1 In 2015, a deadlier attack at the Bardo National Museum in the Tunisian capital city of Tunis resulted in the killing of 21 people by jihadi terrorists (Nance 2016, 111-113). On 3 February 2017 at around 10 am local time, an Egyptian man, Abdullah Reda al-Hamamy, was shot five times outside the Louvre in Paris. Al-Hamamy had used a machete to attack a security patrol protecting the Louvre and the surrounding area in his attempt to access the Carrousel du Louvre, the shopping mall that contains one of the few public entrances to the Louvre museum.

These terrorist attacks have had an impact on museum security in the UK. For example, media reports following the 2017 Louvre incident indicated that several UK museums had implemented enhanced counter-terrorism security measures following consultation with, amongst other agencies, the police. These measures included prohibiting members of the public from entering museums with large items of luggage and the checking of all bags upon entry due to concerns that such items may contain explosive devices or weapons (Gadher 2017). Beyond such indirect impact, museums in the UK have also become a central, direct target of terrorist operational activity. In mid-2017, details emerged from a court case in London that indicated how a UK network of Islamic State-linked fighters, one of whom was killed in Syria, had sought to acquire firearms and explosives in furtherance of a plan to conduct a terrorist attack at the British Museum in London. In mid-2018, a London-based teenager, Safaa Boular, became Britain's youngest convicted female Islamic State terrorist, after the court heard how Boular had planned this attack at the British Museum when she was 17 . Such evidence supports the case that museums in the UK, Western Europe and beyond can be considered as coming within the 
operational purview and targeting calculus of terrorists; with the security impact of such terrorist attacks demonstrating the ability to spread beyond the targeted country.

In response to such developments, this article explores counter-terrorism security practices at museums in the UK; a subject upon which there is a paucity of previous literature or research.2 To fill this gap and providing a new contribution to scholarship in this area of study, we have brought a significant body of research from the field of terrorism and security studies into the museum setting for the first time. The resulting methodology and analysis further informed by the three authors' complementary expertise in policing, museums and terrorism studies, respectively, both reveal the current experience of contemporary terrorism within the museum setting and serves as a framework for the continued monitoring of how museums navigate the complexities of threat, risk and security.

The museum, as a socio-cultural institution that symbolises and communicates the particular values of the political community within which it is located, can be considered an attractive target for terrorist groups. In one of the few studies on this issue, Atkinson, Yates and Brooke (2019) re-interpreted the museum as a terrorist target, noting that even the shifting nature of the contemporary museum does not negate its symbolic significance in the targeting calculus of contemporary terrorism. In doing so we argued that the power of the single narrative of global jihadism can effectively frame an array of contemporary and historic events and practices, rendering both the old (imperial) museum and the new (multicultural) museum as legitimate targets due to the political symbolism of both ideas: the former as representative of colonial power and imperial exploitation; the latter as an expression of contemporary ideologies and values of democracy that are antithetical to extremist views. Such symbolism is compounded by two intersecting features of the contemporary museum: its 'iconic' status and that it constitutes a 'crowded place'; the latter of which has become an increasingly problematised concern in counter-terrorism practice. Claudia Aradau, for example, has noted how crowded places are a recent concern in counter-terrorism security thinking, with an expanded definition of crowded places underpinning emergency planning and, ultimately, modes of security governance (Aradau 2015). The particular features of the museum - its iconic status and that it constitutes a 'crowded place' - provide the clear potential for terrorists to inflict mass casualties and attract significant media and political attention. 3 In fact, it is here, where terrorists can seek to gain renown for their cause (through international media exposure) and enact violent revenge (through mass-casualty attacks) and that the museum may be regarded most acutely as a potential target of terrorist violence.

In this context, where the museum is targeted for both its practical status as an iconic crowded place and its symbolic significance as a representation of broader political culture, particular interest is afforded to the key actors and agencies involved in assessing the nature and extent of the terrorist threat to museums and those responsible for recommending and implementing counter-terrorism security measures in the museum environment. In doing so, this article develops two key lines of inquiry. First, the research explores the nature of current counter-terrorism security practices at museums and the perspectives of museum practitioners on such measures. This section signposts the criticality of the role of the museum security manager as the interface between the museum and the UK counter-terrorism policing and security network. Two key challenges facing museum security practitioners are subsequently outlined: the cost implications of implementing counter-terrorism measures, and the cultural challenge of communicating a counter-terrorism message and responsibly embedding security thinking in everyday practice in the museum environment. Second, this research goes beyond an evaluative analysis of museum security, taking the vital next step of placing that analysis back within the context of the purpose, goals and experience of the contemporary museum. To that end, the research reflects upon the potential consequences of the securitisation of museum spaces, particularly engaging how such measures may impact upon those individuals deemed to be from 'suspect communities'. If one accepts the view that museums have, amongst a constellation of 
priorities, interests and objectives, an educational role as a public service (see Thelen 2005; HooperGreenhill 2007), then securitisation practices must be considered critically for their exclusionary effects and potentially discriminatory consequences. Any failure to recognise this, and its importance in guiding the future provision of security measures at museums, may simply reinforce the divisive narrative propagated by jihadist terrorists.

\section{Research methods}

This article was informed by data from a team-based qualitative study, wherein three researchers deployed a variety of coordinated data collection techniques across a relatively short but intensive period of fieldwork. Due to the interdisciplinary nature of both the research topic and our own research backgrounds, a unique methodology was developed, informed by our past experiences of data collection within and from the institutions of study, namely UK police forces and museums. The primary purpose of this methodology was to overcome the internal institutional pressures that normally prevent these bodies from releasing information, particularly about socially and procedurally fraught topics such as counter-terrorism security practice. As such, our data gathering included both freedom of information (FOI) requests, which the institutions in question were legally obliged to respond to, and voluntary first-person interviews with police and museum professionals. Overall, this research design was underpinned by pragmatism: both in relation to the methods and the underlying philosophy.

The research process began in February 2017 and quickly resulted in the submission of FOI requests to 48 police forces and the 40 most-visited museums in the UK; the intention of which was to establish a baseline of the extent to which museums have been subject to, and participated in, counterterrorism security measures and practices. Responses to these requests for information varied, with some institutions more willing to supply information than others. Overall, 38 responses were received from museums and 48 from police forces. The responses ranged from the refusal to supply any information on the grounds of national security (including almost every police force and some museums) to the comprehensive provision of policy documents, security structures, training, protocols and communications pertaining to counter-terrorism measures in the museum (see Atkinson, Yates and Brooke 2019).

Drawing on the data received following from these requests and by exploiting our own respective professional networks - using a combination of convenience and snowball sampling - we then negotiated access to practitioners in the fields of museums, policing and counter-terrorism in order to further explore insider perspectives on this topic. The principal research method employed for this second stage of fieldwork was semi-structured qualitative interviewing which, in contrast to the mandatory, or even forced, nature of the responses to the FOI requests, allowed for personal reflection on the lived realities of security within a museum setting. A range of recognised approaches and instruments were used to conduct these interviews, including 'conventional' face-to-face techniques (see King and Horrocks 2010), telephone interviews (see Holt 2010), and online interview, including via Skype (see O'Connor and Madge 2017), of professionals working throughout the UK. Data from interviews was digitally recorded where ethically and practically possible, and at the conclusion of fieldwork the researchers had interviewed 20 participants. The data produced from both stages of this fieldwork was imported into the NVivo qualitative analysis software package for thematic coding and subsequent analysis. In reporting the data, this paper has taken measures to protect the anonymity of research participants. Pseudonyms are used for all interviewees. This not only allowed the participants, at least in some cases, to speak from experience, rather than in their official capacity, but also respected the sensitive operational aspects of discussing preparedness for terrorism-related events. While we do not believe that any participant revealed information that would put their institution or organisation under further risk of terrorism, anonymity ensures that minor details shared with the researcher and reported herein cannot be exploited for nefarious ends. 


\section{Current practices and practitioner perspectives}

Based on an analysis of the responses to $\mathrm{FOI}$ requests and an analysis of both terrorist propaganda and recent operational activity, we have re-interpreted the museum and its meaning within the 'single narrative' of global jihadist terrorism; an outlook that justifies and legitimises the targeting of sociocultural sites from instrumental and symbolic perspectives (see Atkinson, Yates and Brooke 2019). Nevertheless, drawing upon the qualitative data from the second stage of our research, it became apparent that museums do not feature especially prominently in the thinking of UK counter-terrorism security and policing practitioners. Other targets - such as transport infrastructure, aviation, shopping malls, sports and music arenas, political institutions and public streetscapes - are instead at the forefront of threat assessment and security delivery. However, the research did uncover counterterrorism practice at museums in the UK, and particularly the important roles of the police Counter Terrorism Security Adviser (CTSA) and the museum security manager in highlighting the risk of terrorism to the museum and in managing such risks in the museum environment and everyday practice. These findings are expanded in the following sections.

\section{Highlighting risk: the police Counter Terrorism Security Advisor}

As a specialism in UK policing, the CTSA is now well established, having been developed and implemented in the post-9/11 period.4 The CTSA role was initially undertaken by sworn police officers, but the current cadre comprises a mix of both police officers and civilian staff. CTSAs are based locally in police forces and counter-terrorism hubs across the UK, with the primary responsibility to provide protective security advice to private businesses and public sector organisations to prevent, and mitigate the effects of, terrorist acts. The CTSA is responsible for both location-specific site appraisal and the raising of public awareness of terrorism through initiatives such as Project Argus and Project Griffin, which aim to enhance resilience (see Malcolm 2013; Prenzler and Sarre 2014).5 CTSA work is therefore firmly aligned to the Protect pillar of the UK counter-terrorism strategy CONTEST.6 In the delivery of their duties, CTSAs must be fully aware of the contours of the current and emerging threat landscape. This is achieved through, first, close collaboration with police colleagues working in areas of policing aligned with other pillars of CONTEST, particularly Pursue. Second, CTSAs also receive threat assessments and strategic intelligence products from intelligence agencies and then 'push out' the threat picture to the businesses and the public. Although this work is delivered locally by CTSAs, it is also coordinated through the National Counter Terrorism Security Office (NaCTSO), with focus on three key workstreams: crowded places; critical national infrastructure; and hazardous sites and substances. The museum sector falls within the first of these workstreams.7

Given the constraints on resources across policing, and the sensible requirement to focus security attention on where it is most needed, crowded places are risk assessed by CTSAs on the basis of three factors: the threat of a terrorist attack at a location; the location's vulnerability to any such attack and the impact of an attack should one occur. Crowded places are subsequently categorised as high risk, medium-high risk, medium risk or low risk; with the intensity of security attention afforded to each category of sites decreasing from high to low (see HM Government 2012, 5-6). In practice, this may mean that sites categorised as low risk do not get CTSA input, with risk instead managed through nonspecialist local police crime prevention resources. Those higher risk crowded places are likely to receive site-specific risk assessment by a CTSA. The extent to which museums featured across this risk assessment matrix varied. During interview, an experienced CTSA remarked that museum security did not feature greatly in practitioner thinking, but that 'Now that you mention it, museums probably are a target' (Jack). However, when the issue was raised there was recognition from CTSAs that frequency of footfall and the symbolic, sometimes iconic, status of museums could be factors in raising the potential risk of terrorist attack. For Barry, a CTSA, whilst the risk assessment process for crowded places is governed by a matrix that ultimately categorises the level of security provision, an important supplementary question in judging the overall risk is 'is it iconic?'. Indeed, Jack, having initially been somewhat surprised by the idea of museum as a terrorist target, later reflected upon the tension 
between the museum as simply a crowded place, but also as an iconic site with broader symbolic meaning and societal resonance:

So this [museum], and the [mentions nearby museum in same city], they are crowded places, but they are also iconic sites. It is more than just a shopping centre with loads of people. It is also an iconic site. You wonder if, every year they release visitor figures, and you wonder if that is just drawing up a target list! (Jack)

This combination of both footfall and the iconic status of particular museums was ultimately recognised as constructing the museum as a potential target. 8 Where sites, including museums, are risk assessed by CTSAs creative protagonist thinking, or 'thinking like a terrorist', is vital. For one police officer participant the CTSA role involved:

Thinking like a bad guy... if you were a bad guy planning [an attack], how would you do it? And then you make a plan based on what you think the bad guy's new logic might be. (Gary)

For another:

It's essential for a CTSA to get in the mindset of someone who is trying to do damage, or has hostile intent. I think that is really where the police or military element, thinking like an adversary comes in; 'how would I attack this building?', I always think that, 'how would I bypass security, guards', all that sort of thing. (Norman)

This approach assists CTSAs in appraising particular locations, including museums, and communicating potential security measures to these sites with a view to reducing vulnerability to attack, enhancing emergency planning protocols, and promoting organisational resilience.

Over and above the risk assessment of museums based on an 'objective' crowded places risk assessment tool and 'thinking like a terrorist', data obtained through FOI requests demonstrated the extent to which counter-terrorism security has become a routine feature of museum security in the UK. Examples of such activity at UK museums included the attendance of museum staff at CTSA-led awareness-raising training events (Project Argus and Project Griffin) and the communication of police counter-terrorism messages to museum staff via a range of media and formats: from videos hosted on museum intranet sites to posters and leaflets in communal staff areas. Additionally, this data also indicated the ways in which museums themselves have taken on responsibility to deliver counterterrorism training and awareness raising, through internal security briefings to a range of staff. Importantly, this data further indicated how CTSAs and museums are networked, allowing for the rapid communication of advice between counter-terrorism security agencies and museums. UK museums are embedded in wider protective security networks that include other crowded places and visitor attractions (see NaCTSO, 2014), across which there is communication concerning issues like changes in terrorism threat levels and the appropriate security response. Moreover, disclosed data showed that museums also receive bespoke communication from CTSAs in response to terrorist attacks at similar locations elsewhere. For example, advice given by a CTSA to a large museum in London in response to the aforementioned attack at the Bardo Museum in Tunisia included the hope that this event had not caused 'panic or alarm' at the museum and that (at that time) there was 'no information to suggest an attack is being planned on museums/galleries or cultural sites in the UK'. This email, sent just over 24 hours after the attack ended, was titled 'Subject: Tunisia'. Significantly, there have been important developments at museums in recent years around who at the museum receives such communication and the subsequent management of risk. 
Managing risk: the museum security manager

The FOI requests sent to museums asked for, amongst other information, details of which roles within the museum are directly responsible for managing and delivering museum security. Predictably, museums diverged in the exact nature and distribution of roles and responsibilities. Yet there emerged a clear pattern in which a named 'museum security manager' is responsible for security - understood in its broadest sense - across the museum. Typically, the museum security manager will lead a team of 'frontline' staff with a security remit, coordinate the wider delivery of security, and report on security matters to the senior leadership team.9 Museum security is not a new area of practice, but it is one that has been subject to recent processes of professionalisation. The employment of dedicated museum security officers - many of whom have been 'outsiders' to the museum, coming from policing, military or other security backgrounds - has been an important development in delivering security and managing risk. For one museum security manager:

The security officers who were here 20 years ago would come on a night shift and lock the doors and get a bottle of Scotch out! We have moved on dramatically from then. (Vinny).

For another, reflecting upon how the terrorist threat has been a catalyst for professionalisation:

There was a realisation that it [museum security] needed to be professionalised. We have old photographs of the police doing security here, but it was just guarding the collections. But there has been an evolution, recognising that the public coming in need protecting. It's more professional now. When I arrived I got a hard time about the tactical options being deployed as the threat level wasn't as high, but not now. We are way up the agenda. (Wilson).

As part of their role the professional museum security manager will also be a central point of contact for communication with the local CTSA in relation to counter-terrorism security. They thus represent a vital node in the aforementioned network of counter-terrorism security practice.

A CTSA, in conducting a site appraisal of a museum, will produce an 'action plan' or a series of recommendations for counter-terrorism security measures to be implemented by the museum. This may include suggestions for alterations to physical security or changes to matters such as staff training. A challenge for any such action plan, however, is the cost to museums of implementing such measures, which can be expensive, particularly when measured against the low-probability, but potentially high-impact, risk of terrorist attack. In this regard, it was recognised that an important skill for the CTSA was to recommend counter-terrorism security measures that were proportionate and realistic. A CTSA reflected on this issue at some length:

Getting museums to actually deal with recommendations, probably was always a bit of a challenge. Purely due to financial issues... but they always engaged really closely with CTSAs. How many recommendations they actually put in place is another matter. Purely due to financial constraints... It is an ongoing process of engagement to try and coax them into implementing some of the advice. And some of it costs very little, and some of it is obviously is extremely expensive. And some of the training is provided free of charge by the police, provided through the CTSA network at no charge, but there is still the opportunity cost for the museums of obviously they lose their staff from their normal role for a whole day, which obviously is a not inconsiderable cost to them. (Perry).

Another CTSA noted how, having conducted a site appraisal, 'risk' was then shared by the museum: 
A lot of the recommendations are about proportionality. If you get the mitigation right and it is proportionate and the client can see that, but at the end of the day it is only guidance. There is no real financial incentive, but there is a bit about passing the risk on to try and engender some activity. It depends on how risk averse the client is, whether they want to do anything about it or just accept hat risk. Some of the museums they just don't have the money to do it. If you suggest replacing all the glazing in a grade one listed with laminated glass, you are talking a colossal amount of money. So very difficult, and it is trying to get a reasonable balance to the threat they have. (Norman).

Interestingly, a museum security manager noted how he used the close working relationship with the CTSA and developments in the threat to prompt a response to the CTSA report:

I delivered that [site appraisal] to the museum leadership team to say 'this is where we are'. To be honest there wasn't much movement, and then following a follow-up from the police CT department there was an email [from the police] asking for what procedures have been put in place following the Paris attack. Of course we hadn't done any, and we have now ticked off our entire list because of that. (Mark).

Fieldwork also indicated how costs for counter-terrorism security measures can sometimes be dealt with through collaboration between museums, particularly between those located in close proximity to one another and who share common risks.

Museum security managers seek to communicate a security message, including awareness of threats from terrorism, across the museum. In practice, this can take several forms. As well as the aforementioned delivery of counter-terrorism training and awareness-raising events by CTSAs to museum staff, commonly organised through museum security managers, an array of communication strategies were evidenced in our research.10 Museum security managers co-ordinated, for example, the use of museum staff intranet systems to 'constantly remind' staff of the risk of terrorism by directing them to relevant publicly available guidance and information, as well as the use of both email systems and information posters in staff room areas to disseminate counter-terrorism security information. Other examples of communication and preparedness included: routine staff briefings on terrorism, the rehearsal of emergency response and security procedures through exercises, including both evacuation and invacuation/lockdown procedures as relevant to developing threats.

Any understanding of the nature of such tasks, however, must appreciate that museums are not monolithic, but are heterogeneous and compartmentalised. They are comprised of diverse and distinct departments that are staffed by specialists in their respective fields - from finance, administration and commercial operations to human resources, education and collections - each of which will have their own values, tastes, dispositions and worldviews. An important emergent theme in fieldwork was a recognition that the needs and expectations of curatorial staff, as specialists and experts in the museum, may not always accord with the 'dark message' of counter-terrorism security, which, if it is to be embedded in a museum environment, requires 'huge cultural change' and the 'management of staff anxieties' (Eamonn). Museum security managers recognised that they, as new actors in the museum space and bringing with them particular forms of cultural capital, encountered issues in obtaining support for the changes they sought to implement:

So when I moved in to the museum sector they created a post of the head of security and the vision was for me to come in and review policies, procedures and see what changes we could make to a security system or workforce... but the biggest challenge as actually the sector itself. Because when I came into the museum I didn't come from an academic background, I came from the forces and the commercial sector, which was renowned for 
being quite cutthroat. So it was quite a challenge getting anything through, that wasn't from a leadership point of view but from a staffing point of view. So more the curators were my challenge... It was about cultural change or change full stop... My point of view coming from a security sector and into an academic sector was just that they [curatorial staff] very much think differently. (Wilson).

Such resistance was compounded by the perception that the terrorist threat to museums was low and that, despite attacks elsewhere, such as those in Tunisia and France, a terrorist attack was 'not gonna happen here' (Norman). ${ }^{1}$ Nevertheless, efforts have also been made to attune staff to the potential terrorist threat through counter-terrorism awareness-raising training. Asked about whether curatorial staff considered security issues in their duties a museum security manager reflected,

If you'd asked five years ago I'd have said no... It's been an educational process. Baby steps, getting them to understand that when they put an exhibition together security needs to be brought in right at the off [beginning]. We've done a lot of work on that. (Kevin).

Whilst progress has been made, ensuring that the full range of museum staff - from security officers and visitor support to directors and registrars, curators and conservation experts - individually and collectively recognise the security imperative will remain a challenge.

\section{The securitisation of the museum}

The preceding analysis has indicated how, more so than ever before, museums in the UK have been dedicating resources towards, and professionalising, counter-terrorism security practice. This has resulted in the implementation of a range of security practices hitherto unheard of, and unthought of, in these particular spaces. However, with the emergence of such new security practices one must be attuned to potential issues of securitisation, whereby the framing of particular issues through the lens of security necessitates the deployment of specific forms of knowledge, capacities and resources in response, and the particular forms of security that are imagined shape mentalities and practices of governance. Such responses are, as Louise Richardson discussed, 'what terrorists want'. In her booklength study of this topic, Richardson (2007) argued that terrorists seek three overarching objectives: revenge, renown and reaction. We have expanded elsewhere upon the symbolic and communicative aspects of targeting museums for terrorist violence, and the single narrative that underpins this operational activity (Atkinson, Yates and Brooke 2019). The targeting of museums in such contexts fits Richardson's model of 'revenge' and 'renown'. However, we expand the analysis here to include an appreciation of how the 'reaction' of museums to terrorist threats speaks clearly to existing and emerging practices of securitisation.

The classic conceptualisation of securitisation highlights the call to consider the extraordinary and existential nature of a particular 'threat' which, in turn, necessitates the use of emergency measures (Buzan, Wæver, and de Wilde 1998, 26). In this sense, securitisation is a form of acute politicisation that, in a sense, de-politicises the referent subject. A burgeoning literature has emerged on both the theory of securitisation (see Balzacq 2011) and analyses of securitisation in practice. This latter body of literature, which includes considerations of the securitisation of an array of both communities and spaces in response to terrorist threats, discloses valuable insights that can be gainfully applied to the neglected subject of the museum space. For example, existing research on the securitisation of airports provides a useful knowledge base from which to contextualise and inform counter-terrorism security measures at museums. Research in Scotland has indicated the ways in which security

\footnotetext{
${ }^{1}$ Such perspectives were not shared by museum security managers who recognised that an attack on 'culture' would be attractive to terrorists, wherein the museum would be attractive for its iconic or symbolic status, as well as its ability to generate publicity (Billy).
} 
practices at airports in the post-9/11 era have led to a perception by some Scottish Muslims, particularly those from the South Asian community, of being stereotyped, targeted and discriminated against (see Bonino 2017, 134-135). Similar findings were reported by Blackwood, Hopkins, and Reicher $(2013,2015)$ whose research with Scottish Muslims highlighted how this community considered airports as a site of humiliation, distress, injustice and, on occasion, fear, where encounters with authorities and security actors produce both personal and collective anxieties that have profound effects on identities, citizenship and belonging. Such accounts of the consequences of the securitisation of everyday spaces are not limited to Scotland; similar experiences have been highlighted in studies in other areas of the UK (see Choudhury and Fenwick 2011), as well as further afield (see Salter 2008; Hasisi and Weisburd 2011; Jonathan-Zamir, Hasisi, and Margalioth 2016; Ergün, Açıkel, and Turhan 2017).12 Importantly, Zedner $(2009,149)$ highlights that security technologies, policies and practices that are initially considered as 'exceptional', such as those at airports, are subsequently replicated and routinised in other spaces of everyday life. Museums have become a firm case in point, where visitors can now routinely expect to be subject to and experience bag searches, hostile vehicle mitigation (HVM), and the screening and interpretation of 'suspicious' visitor behaviour.13 In this way, the museum can now be appropriately considered as another site in the securitisation of 'frontline leisure' (see Lisle 2013).14 Significantly, however, even amongst museum security managers our fieldwork highlighted a recognition that whilst counter-terrorism security measures are now necessary the museum should not become a 'fortress', and any such practices must be balanced against the museum's core purpose and values of diverse public engagement (Billy). Following the spirit of this position, the securitisation of the museum should be a development that is subject to scrutiny and critical challenge, particularly given the impact of counter-terrorism security measures on minority communities.

The 'high policing tactics' that are often linked to securitisation, and which have become embedded in everyday policing practice, can be experienced by the public, and particularly minority groups, as threatening, humiliating, intrusive and insensitive (see Jonathan-Zamir, Hasisi, and Margalioth 2016, 613-614). Several studies in various contexts have demonstrated how processes of securitisation, and the counter-terrorism policies and practices used in the pursuit of security, can have a discriminatory, stigmatising, marginalising or alienating effect, creating and sustaining 'suspect communities' in the climate of prevailing terrorist threats (see Hickman et al. 2007; Brown 2008; Breen Smyth 2009; Pantazis and Pemberton 2009; Spalek 2010, 2011; Awan 2012; Mythen 2012; Mythen, Walklate, and Khan 2013; Ajala 2014; Vermeulen 2014). Certainly, the ethics and morality of securitisation are of interest to scholars, practitioners and the general public (Floyd 2016, 80-82). A common sensibility has thus been to consider securitisation pejoratively: as a negative, exclusionary and inherently undemocratic phenomenon that must be tackled through de-securitisation (see Aradau 2004).15 Salter (2008) and Côté (2016) have separately argued that the reimagination of the securitisation 'audience' as an active agent, located within an iterative and contextually situated process, opens the possibility of their having an independent effect on securitisation and de-securitisation outcomes. Such a perspective heralds promise and potential pitfalls. Research on 'everyday' conceptions of counterterrorism in the UK suggests that - contrary to the suggestions of securitisation theory - members of the public may not consider themselves automatically disqualified from participating in counterterrorism policy discourse due to a lack of expertise, understanding or structural advantage in the British political establishment. In fact, British publics seem inclined to actively engage in counterterrorism policy discussion, including participation in debate over appropriate practices (Jarvis and Lister 2016). Any such engagement, however, would not be straightforward. In his critique of the 'suspect community' thesis, Ragazzi (2016) cautions against the more insidious political effects of counter-terrorism policies based on the active participation and involvement of some Muslims in their own policing, thus challenging the notion of 'community' itself. 
In 1993, Jay Chambers coupled terrorism alongside vandalism in considerations of security threats and argued that museums - or more specifically the objects and artefacts on display in museums - are an unlikely terrorist target where such institutions have a positive public reputation. Whilst Chambers' account is clearly dated in the context of the contemporary threats, he presciently remarked that overreaction by museums to terrorist threats is also problematic (Chambers 1993, 71). This cautionary account seems still relevant in the current threat landscape. The implementation of counter-terrorism security practices at museums should not be seen and cannot be reduced to a technocratic, apolitical exercise. In many ways, the museum may in fact be well placed to develop appropriate, proportionate and palatable responses to threats from terrorism. The participative, open, transparent and accountable civic museum seeks to engage in dialogue and the co-production of meaning making in the contemporary curation and exhibition of cultural artefacts and objects (see Thelen 2005); and it should approach the implementation of counter-terrorism policies and practices with a similar outlook. Chakraborti $(2007,121-122)$ has highlighted how, in a climate where the rhetoric of security looms large, the way in which minority communities are engaged in relation to policing and security has a significant bearing upon how much measures are received. Drawing upon the recent move of museums towards genuine public engagement and development of open dialogue in relation to exhibitions and artefacts, the contemporary civic museum is well equipped to develop a response to terrorism that is proportionate and effective; reducing the risk of distancing itself from, alienating, and effectively 'othering', minority communities in a society increasingly governed through the rhetoric and practices of security. Reflecting on the civic role of museums in Glasgow, Scotland's largest city, Fiona McLean and Mark O'Neill have noted how,

On the basis that the museums reflect civic values, Glasgow Museums' programme targets hitherto excluded groups, and reflects their culture. Along with traditional subjects exhibition topics have included: Homelessness, The Veil in Islam, Gay History, Women and War, Voodoo. As well as celebrating human creativity and the diversity of cultures, the museums regard it as their role to challenge negative heritage, including racism, sectarianism and domestic violence, all of which have been the subject of exhibitions and education programmes. (McLean and O'Neill, 2007: 222).

In practice, therefore, the civic museum through its ongoing local engagement activities, but also through its own artefacts and exhibitions, can seek to negate any exclusionary and othering consequences of securitisation by representing and including those very 'suspect' communities who may feel excluded from the museum and othered by its security practices.

\section{Conclusion}

This paper has demonstrated that the museum has been a site of terrorist violence on multiple occasions and in a variety of jurisdictions in the past decade. In uncovering the key actors and agencies involved in assessing the nature and extent of the terrorist threat to museums in the UK, and those charged with implementing counter-terrorism security measures in response, this paper has particularly highlighted the important roles of the police CTSA and the museum security manager in mitigating such threats. Two inter-related challenges facing museum security were discussed: the cost of implementing counter-terrorism measures at museums, and the cultural challenge of communicating a counter-terrorism message and responsibly embedding such security thinking in everyday practice. The paper concluded by reflecting upon the potential consequences of the securitisation of museum spaces as part of a wider counter-terrorism security imperative, highlighting the potential for such measures to be experienced disproportionately by individuals from 'suspect communities', with important exclusionary consequences. This represents an important area for future inquiry. 
By tracing the current terrorist threat to museums, this article injects some impetus into practitioner thinking around counter-terrorism security in this space, as well as promoting thoughtful consideration of the potential consequences of any such measures. Reflecting upon the emergent critical focus in terrorism studies, Jackson $(2009,362-363)$ has noted that there are serious ethicalnormative questions to be considered in researching and publishing in this field, particularly when scholars generate research and policy recommendations for state counter-terrorism actors. Our research is sympathetic to such positions. We, as researchers, are cognisant of the consequences of 'speaking security' to sensitive topics (Neal 2017) and we recognised our potential impact on the contemporary UK museum-scape by bringing such security considerations to the fore. Our research does not seek to be alarmist or over-state the extent to which terrorists may be interested in targeting museums, but we are also cognisant of risk. The former senior UK counter-terrorism practitioner Sir David Omand recently recognised the contemporary dilemma as how best to protect the public in the face of a severe terrorist threat while maintaining civic harmony, protecting the rights and liberties of citizens, upholding human rights and democratic values, and managing the unwanted consequences of counter-terrorism security measures (Omand 2015, 57). Given the shifts in the threat landscape since 2015, which have brought the museums more firmly into the terrorist targeting purview, Omand's account captures the contemporary challenge facing museums in the UK. 


\section{Notes on contributors}

Colin Atkinson is a Lecturer in Criminology at the University of the West of Scotland. Before becoming an academic Colin was employed in the Scottish police service for nine years as a member of civilian police staff.

Donna Yates is a Senior Lecturer in Sociology based at Scottish Centre for Crime and Justice Research, University of Glasgow. She is a founding member of the Trafficking Culture research consortium (TraffickingCulture.org).

Nick Brooke is an Associate Lecturer in the Centre for the Study of Terrorism and Political Violence at the University of St Andrews. 


\section{Notes}

1 Nemmouche is alleged to have part of an Islamic State external operations cell led by Abdelhamid Abaaoud, the leader of the November 2015 attacks in Paris (Cragin 2017, 217).

2 A comparative study of museum security in Finland and England (Grove and Thomas 2016), although recognising that museum security is under-represented in museological discourse, paid only passing attention to terrorism within a wider constellation of threats. Our more recent research (Atkinson, Yates and Brooke 2019) represents an attempt to more firmly locate counter-terrorism security within existing museum security practice in the UK.

3 Whilst the current security and scholarly gaze is understandably fixated on the issue of mass-casualty terrorism, it must be recognised that the targeting of museums is not an exclusively recent phenomenon. Museums have previously been targeted, for example, by the Provisional Irish Republican Army (see Oppenheimer 2008, 90).

4 To a certain extent, the CTSA role drew upon, at least in part, the skills, experience and outlook of the more well-established 'crime prevention officer role' in policing (for an overview of which see Bowers 2001).

5 In conjunction with, in some force areas, Counter Terrorism Awareness Advisors (CTAAs), whose role is to support CTSAs through the delivery of counter-terrorism security awareness briefings and presentations about the effects of terrorism.

6 The four pillars of CONTEST are 'pursue' (to stop terrorist attacks), 'prevent' (to stop people becoming terrorists or supporting terrorism), 'protect' (to strengthen protection against a terrorist attack) and 'prepare' (to mitigate the impact of a terrorist attack).

7 In some rare instances, CTSAs may also engage with museums that store hazardous substances.

8 Interestingly, Mcllhatton et al. (2018), in their analysis of the issues that inhibit the adoption of counter-terrorism protective security measures in real estate development, noted how their research participants considered the likelihood of a terrorist attack low, if it was considered at all, due to their view that their sites were 'not iconic'.

9 'Frontline staff' may be dedicated internal museum security staff, other museum visitor services staff, private security contractors hired by the museum as required, or any mix thereof.

10 Interestingly, it was also disclosed in research that some private security contractors employed by museums were also accredited to deliver police counter-terrorism awareness training.

11 Such perspectives were not shared by museum security managers who recognised that an attack on 'culture' would be attractive to terrorists, wherein the museum would be attractive for its iconic or symbolic status, as well as its ability to generate publicity (Billy).

12 Compared to the number of studies of those who experience securitisation, the cultures and practices of those who put securitisation into everyday effect remain under-represented in the research literature (see Maguire 2014).

13 Mike Maguire's research on airport security highlights, for example, the use of the Behavioural Assessment Screening System (BASS) by practitioners to surveil passengers and identify suspicious behaviours and activities (Maguire 2014, 130). 
14 In the United States, for example, Frost (2017) has remarked upon the 'security gauntlet' that must be overcome in order to enter the National September 11 Museum in New York, in a process very much akin to airport security.

15 Although this dichotomous position of securitisation/negative and de-securitisation/positive has been de-essentialised by Roe (2012) in an effort to enable engagement with alternative security forms and practices. 


\section{References}

Ajala, I. 2014. "Muslims in France and Great Britain: Issues of Securitization, Identities and Loyalties Post 9/11." Journal of Muslim Minority Affairs 34 (2): 123-133.

Aradau, C. 2004. "Security and the Democratic Scene: Desecuritization and Emancipation." Journal of International Relations and Development 7 (4): 388-413.

Aradau, C. 2015. "'Crowded Places are Everywhere We Go': Crowds, Emergency, Politics." Theory, Culture \& Society 32 (2): 155-175.

Atkinson, C., D. Yates, and N. Brooke. 2019. "Researching a Risky Business? The Use of Freedom of Information to Explore Counterterrorism Security at Museums in the United Kingdom." Studies in Conflict and Terrorism. Accessed 19 October 2019. doi:10.1080/1057610X.2019.1647682.

Awan, I. 2012. "“I Am a Muslim Not an Extremist": How the Prevent Strategy Has Constructed a "Suspect" Community." Politics \& Policy 40 (6): 1158-1185.

Balzacq, T. 2011. "A Theory of Securitization: Origins, Core Assumptions, and Variants." In Understanding Securitisation Theory: How Security Problems Emerge and Dissolve, edited by T. Balzacq. Abingdon: Routledge

Blackwood, L., N. Hopkins, and S. Reicher. 2013. "I Know Who I Am, But Who Do They Think I Am? Muslim Perspectives on Encounters with Airport Authorities." Ethnic and Racial Studies 36 (6): 10901108.

Blackwood, L., N. Hopkins, and S. Reicher. 2015. “'Flying While Muslim': Citizenship and Misrecognition in the Airport." Journal of Social and Political Psychology 3 (2): 148-170.

Bonino, S. 2017. Muslims in Scotland: The Making of Community in a Post-9/11 World. Edinburgh: Edinburgh University Press.

Bowers, K. J. 2001. "Small Business Crime: The Evaluation of a Crime Prevention Initiative." Crime Prevention and Community Safety 3 (1): 23-42

Breen Smyth, M. 2009. "Subjectivities, 'Suspect Communities', Governments, and the Ethics of Research on 'Terrorism'." In Critical Terrorism Studies: A New Research Agenda, edited by R. Jackson, M. Breen Smyth, and J. Gunning. London: Routledge.

Brown, K. 2008. "The Promise and Perils of Women's Participation in UK Mosques: The Impact of Securitisation Agendas on Identity, Gender and Community." The British Journal of Politics and International Relations 10 (3): 472-491.

Buzan, B., O. Wæver, and J. de Wilde. 1998. Security: A New Framework for Analysis. London: Lynne Rienner Publishers.

Chakraborti, N. 2007. "Policing Muslim Communities." In Policing Beyond Macpherson: Issues in Policing, Race and Society, edited by M. Rowe. Cullompton: Willan.

Chambers, J. 1993. "Vigilance and Guard Services." In Museum Security: A Handbook for Cultural Heritage Institutions, edited by D. Liston. Abingdon: Routledge. 
Choudhury, T., and H. Fenwick. 2011. "The Impact of Counter-Terrorism Measures on Muslim Communities." International Review of Law, Computers \& Technology 25 (3): 151-181.

Côté, A. 2016. "Agents Without Agency: Assessing the Role of the Audience in Securitization Theory." Security Dialogue 47 (6): 541-558.

Cragin, R. K. 2017. "The November 2015 Paris Attacks: the Impact of Foreign Fighter Returnees." Orbis 2: $212-226$.

Ergün, N., B. Açıkel, and U. Turhan. 2017. "The Appropriateness of Today's Airport Security Measures in Safeguarding Airline Passengers." Security Journal 30 (1): 89-105.

Floyd, R. 2016. "The Promise of Theories of Just Securitisation." In Ethical Security Studies: A New Research Agenda, edited by J. Nyman, and A. Burke. Abingdon: Routledge.

Frost, L. 2017. "No Safe Spaces: Notes on the National September 11 Museum." Journal of Urban Cultural Studies 4 (1/2): 221-239.

Gadher, R. 2017. "Museums Put on Alert for Isis Suitcase Bomb." The Sunday Times, 19 February. Accessed 19 October 2019. http://www.thetimes.co.uk/article/museums-put-on-alert-for-isissuitcase-bomb-3wk0h6b3n.

Grove, L., and S. Thomas. 2016. "'The Rhino Horn on Display Has Been Replaced by a Replica': Museum Security in Finland and England." Journal of Conservation and Museum Studies 14 (1): 1-11.

Hasisi, B., and D. Weisburd. 2011. "Going Beyond Ascribed Identities: the Importance of Procedural Justice in Airport Security Screening in Israel." Law \& Society Review 45 (4): 867-892.

Holt, A. 2010. "Using the Telephone for Narrative Interviewing: a Research Note." Qualitative Research 10 (1): 113-121.

Hooper-Greenhill, E. 2007. Museums and Education: Purpose, Pedagogy, Performance. Abingdon: Routledge.

Hickman, M. J., L. Thomas, H. C. Nickels, and S. Silverstri. 2007. "Social Cohesion and the Notion of 'Suspect Communities': a Study of the Experiences and Impacts of Being 'Suspect' for Irish Communities and Muslim Communities in Britain." Critical Studies on Terrorism 5 (1): 89-106.

HM Government. 2012. Crowded Places: The Planning System and Counter-Terrorism. London: The Stationary Office.

Jackson, A. 2009. "Conclusion: Back to the Future of Terrorism Research." Critical Studies on Terrorism 2 (2): 361-363.

Jarvis, L., and M. Lister. 2016. "What Would You Do? Everyday Conceptions and Constructions of Counter-Terrorism." Politics 36 (3): 277-291.

Jonathan-Zamir, T., B. Hasisi, and Y. Margalioth. 2016. "Is It the What or the How? The Roles of HighPolicing Tactics and Procedural Justice in Predicting Perceptions of Hostile Treatment: the Case of Security Checks at Ben-Gurion Airport, Israel." Law \& Society Review 50 (3): 608-636. 
King, N., and C. Horrocks. 2010. Interviews in Qualitative Research. London: SAGE.

Lisle, D. 2013. "Frontline Leisure: Securitizing Tourism in the War on Terror." Security Dialogue 44 (2): 127-146.

Maguire, M. 2014. "Counter-terrorism in European Airports." In The Anthropology of Security: Perspectives From the Frontline of Policing, Counter-Terrorism and Border Control, edited by M. Maguire, C. Frois, and N. Zurawski. London: Pluto Press.

Malcolm, J. A. 2013. "Project Argus and the Resilient Citizen." Politics 33 (4): 311-321

Mcllhatton, D., Berry, J., Chapman, D., Christensen, PH., Cuddihy, J., Monaghan, R. and Range, R. (2018). "Protecting Crowded Places from Terrorism: An Analysis of the Current Considerations and Barriers Inhibiting the Adoption of Counterterrorism Protective Security Measures." Studies in Conflict and Terrorism, Latest Articles. Accessed 19 October 2019. doi:10.1080/1057610X.2018.1507311.

McLean, F., and M. O'Neill. 2007. "The Social Museum' and its Implications for Marketing." In Museum Marketing, edited by R. Rentschler, and A. Hede. Amsterdam: Butterworth-Heinemann.

Mythen, G. 2012. "'No one Speaks for us': Security Policy, Suspected Communities and the Problem of Voice." Critical Studies on Terrorism 5 (3): 409-424.

Mythen, G., S. Walklate, and F. Khan. 2013. "Why Should we Have to Prove We're Alright?': CounterTerrorism, Risk and Partial Securities." Sociology 47 (2): 383-398.

NaCTSO. 2014. Counter Terrorism Protective Security Advice for Visitor Attractions. London: ACPO. $\begin{array}{llll}\text { Accessed } & 19 & \text { October } & 2019 .\end{array}$ https://www.gov.uk/government/uploads/system/uploads/attachment_data/file/375180/VisitorAtt ractions_Reviewed.pdf.

Nance, M. 2016. Defeating ISIS: Who They Are, How They Fight, What They Believe. New York: Skyhorse Publishing.

Neal, A. W. 2017. "To Speak Security or not to Speak Security? Responsibility and Deference in the Scottish Independence Debate." In Security in a Small Nation: Scotland, Democracy, Politics, edited by A. W. Neal, 203-223. Cambridge: Open Book Publishers.

O'Connor, H., and C. Madge. 2017. "Online Interviewing." In The SAGE Handbook of Online Research Methods, edited by N. G. Fielding, R. M. Lee, and G. Blank, 416-434. London: SAGE.

Omand, D. 2015. "What Should be the Limits of Western Counter-Terrorism Policy?" In Illusions of Terrorism and Counter-Terrorism, edited by R. English, 57-72. Oxford: Oxford University Press.

Oppenheimer, A. R. 2008. IRA, The Bombs and the Bullets: A History of Deadly Ingenuity. Dublin: Irish Academic Press.

Pantazis, C., and S. Pemberton. 2009. "From the 'Old' to the 'New' Suspect Community: Examining the Impacts of Recent UK Counter-Terrorist Legislation." British Journal of Criminology 49 (5): 646-666. 
Prenzler, T., and R. Sarre. 2014. "The Role of Partnerships in Security Management." In The Handbook of Security, edited by M. Gill, 769-790. Basingstoke: Palgrave Macmillan.

Ragazzi, F. 2016. "Suspect Community or Suspect Category? The Impact of Counter-Terrorism as 'Policed Multiculturalism'." Journal of Ethnic and Migration Studies 42 (5): 724-741.

Richardson, L. 2007. What Terrorists Want. New York: Random House.

Roe, P. 2012. "Is Securitization a 'Negative' Concept? Revisiting the Normative Debate Over Normal Versus Extraordinary Politics." Security Dialogue 43 (3): 249-266.

Salter, M. B. 2008. "Securitization and Desecuritization: a Dramaturgical Analysis of the Canadian Air Transport Security Authority." Journal of International Relations and Development 11 (4): 321-349.

Spalek, B. 2010. "Community Policing, Trust, and Muslim Communities in Relation to "new Terrorism"." Politics \& Policy 38 (4): 789-815.

Spalek, B. 2011. "'New Terrorism' and Crime Prevention Initiatives Involving Muslim Young People in the UK: Research and Policy Contexts." Religion, State and Society 39 (2/3): 191-207.

Thelen, D. 2005. "Learning Community: Lessons in co-Creating the Civic Museum." In Heritage, Museums and Galleries, edited by G. Corsane, 333-338. Abingdon: Routledge.

Vermeulen, F. 2014. "Suspect Communities - Targeting Violent Extremism at the Local Level: Policies of Engagement in Amsterdam, Berlin, and London." Terrorism and Political Violence 26 (2): 286-306.

Vidino, L. 2014. "European Foreign Fighters in Syria: Dynamics and Responses." European View 13 (2): 217-224.

White, J. R. 2017. Terrorism and Homeland Security. Boston: Cengage Learning.

Zedner, L. 2009. Security. Abingdon: Routledge 